\title{
System of expected indicators of green growth and green economy
}

\author{
Anatoly Shevchuk ${ }^{1,2}$ and Andrey Prorokov ${ }^{3, *}$ \\ ${ }^{1}$ Nature Management and Ecology Division, Vavilova st., 7, Moscow, 117997, Russia \\ ${ }^{2}$ The Russian Presidential Academy of National Economy and Public Administration (RANEPA), \\ Vernadsky Prospekt, 82, 1, Moscow, 119571, Russia \\ ${ }^{3}$ Moscow Region State University, Radio str, 10A, 105005, Moscow, Russia
}

\begin{abstract}
The works, performed for the last three years at the request of various ministries and departments for decision-making on transition of the Russian Federation to green economy, are considered and critically analysed in the article. The purpose is to formulate the main approaches to the measurement of green economy, the concept of transition, measures for realization, etc. The results, received by the authors of this research, were used within the preparation of the meeting of the State Council, held on December, 27, 2016, and they can become the basis for the development of the scientifically proved Concept of transition of the Russian Federation to green economy and for the preparation of "Methodological recommendations on the inclusion of an ecological component in investment projects of regions in Russia". The research was carried out on the basis of the Russian practice. However the research materials can be used both by domestic and foreign experts, who are engaged in studying green economy, green growth, green technologies, sustainable development, greening of economy, and for the heads, who are responsible for the economy development.
\end{abstract}

\section{Introduction}

The subject of transition to green economy rose on the political agenda in the end of the 2000th. Programmes and strategies of transition of the countries of OECD to "green" economy were developed, there were international documents, which promoted the change of the economic, political and ecological landscape; that led to the development of recommendations on the transition to "green" economy of the developing countries.

Having signed some international documents, Russia also appeared in a situation when adoption of the ideology of "green" economy had to be the following logical step. This decision was ambiguously apprehended in political and economic circles and caused various controversy. In this regard some ministries and departments attended to problems and prospects, and, above all the concept of transition of the country to "green" economy. So, in 2013-2016 the Ministry of Natural Resources and Environmental Protection of the Russian Federation, the Ministry of Economic Development of the Russian Federation and

\footnotetext{
*Corresponding author: meo.prorokov@yandex.ru
} 
the Ministry of industry and trade of Russia acted as initiators of the researches on the "green" perspective.

There were many new books and publications on "green" economy in Russia and abroad, this subject is rather new, but it already received multipage bibliographic indexes in Russia and abroad.

The splash in publications during the last years was caused by strengthening of interest in "green" economy, which is suddenly considered by economists, politicians, researchers, businessmen as the mechanism for reform of the economic and financial system to make it steadier, transparent and less subject to great risk of bankruptcy, which brought us to the economic crash. "The crack in armor of the economic infallibility created the political space for integration of the environment into economic thinking" [1].

The publications by the United Nations on the environment (UNEP), which have appeared recently, including Report on "green" economy (UNEP, 2011) [2], Intermediate Report on "green" growth, prepared by the Organization for Economic Cooperation and Development (OECD, 2010) [3], Final Report on "green" growth (2014) and the Road Map of the decrease in content of carbon till 2050 [4] issued by the EU (2011) are the striking examples of such thinking.

The concept of "green" economy" was discussed originally in the specialized communities, relating to environment economy; then it began to be considered at the international meetings on sustainable development. The interest of such meetings in "green" economy was also connected with the disappointment caused by failures of the markets, the economic and financial crisis of 2008. Thus, the new stage of interest in "green" economy was connected with the search of the perspective direction, new paradigm of economic development in which the material wealth has to be insured from the increase in the environmental risks happening because of resource depletion and expansion of social inequality [5].

"Green" economy as it was defined in the environment protection programme of launched by the United Nations in February, 2011 has to lead to the improvement of welfare and social justice, due to considerable reduction of the environmental risks and ecological deficiency.

The term "green" economy has different treatments, however, unlike other definitions, these definitions are almost uniform. The "green" economy in traditional, narrow sense, is defined as the economy which leads to the reduction of environmental risks and ecological deficiencies and which seeks for sustainable development without any damage to the environment. It is closely connected with the ecological economy, but has more political applied focus [6].

In the broad sense the "green" economy" is considered to be en economy, which is compatible to sustainable development, and this new form of economic development should be considered as the long-term adaptation of the economic system to various crises, which can arise [6].

The concept of "green" economy" was formulated by Karl Burkart, on the basis of six main components [7]:

a) renewables;

b) "green" buildings;

c) sustainable development of transport;

d) management of water;

e) waste management;

e) land management.

It is obvious that in the 2010th the approach to "green" economy changed in comparison with the 1970th, when the matter only began to arise. Not only approaches to "green" economy change, the system of its measurements, whuich is not created yet, began to 
change. Changes happen against the background of recognition of the fact that the system of world economic indicators does not characterize adequately world economy during the era of its innovative development and definitely does not describe economic processes [3].

\section{Methods}

Council for studying of productive forces (CSPF) of the All-Russian Academy of Foreign Trade (ARAFT) with the participation of experts from other organizations, including from MGOU, made a series of applied economic researches on "green" economy and "green" growth according to the order of the Ministry of Economic Development of the Russian Federation custom [10].

During the work on the report several sources were used, including:

- international legal and normative documents, devoted to "green" economy and its measurements and also standard and legal documents of the Russian Federation;

- Internet resources: the networks uniting the organizations entering into various associations on "green" economy including network of experts in the field of measurement of "green" economy and its growth; websites of the international organizations which are responsible for development of measurements in the industry; the websites publishing materials on "green" economy;

- interviews with heads of different level and researchers in the field of "green" economy;

- reports by CSPF of 2013 and 2014 in which the problems of "green" economy were consistently considered [10];

- reports by the ministries and departments of the EU dealing with issues of "green" economy and industry reports of the associations uniting experts in the field of renewables, "green" construction, etc.

As the result of the conducted research the analysis was made, including:

- international documents and recommendations of conferences, summits on environmental protection and sustainable development, including, Declarations of the UN on the environment (Rio de Janeiro, 1992), final documents of the Conference of the UN on sustainable development (Johannesburg, 2002), of the Conferences of the UN on sustainable development "RIO +20", of the summits of G8 countries during 1997-2012, of the summits of the countries of top-level "Group of Twenty" during 2008-2012, of the summits of the countries of APEC during 1997-2012 and also the last documents of OECD, World Bank, YuNEP, GGGI, etc.;

- methodological approaches of the international organizations (the UN, YuNEP, PROON, OECD, YuNIDO, the WTO) on the reflection of indicators of "green" growth and "green" economy in documents of strategic and predictive character;

- the activity of the international organizations for development of the integrated indicators;

- the practice of transition to the principles of "green" economy, existing in the Russian Federation in certain sectors of economy and activities: "green" technologies, "green" power, "green" transport, "green" construction, ecosystem services.

\section{Results}

Offers on the structure of expected indicators and indicators of "green" growth and "green" economy as a part of the forecast of long-term social and economic development of the Russian Federation until 2030, taking into account the existing documents of strategic planning (Table 1), were developed. 
Table 1. Quantitative assessment of expected indicators and indicators of "green" growth and "green" economy as a part of the forecast of long-term social and economic development of the Russian

Federation until $2030 *$.

\begin{tabular}{|c|c|c|}
\hline Recommended indicators & $\begin{array}{l}\text { Current } \\
\text { value of the } \\
\text { indicator }\end{array}$ & $\begin{array}{l}\text { Value of the } \\
\text { indicator } \\
\text { in } 2030 .\end{array}$ \\
\hline Total amount of emissions of pollutants (million tons) & 32.6 & $16-20$ \\
\hline $\begin{array}{l}\text { Volume of emissions of pollutants from stationary sources (million } \\
\text { tons) }\end{array}$ & 19.2 & $12-14$ \\
\hline $\begin{array}{l}\text { Emission rate of pollutants (specific emissions) (per unit of, GDP } \\
\text { ton per million roubles of GDP) }\end{array}$ & 0.3 & 0,2 \\
\hline $\begin{array}{l}\text { Emission rate of pollutants from stationary sources (per unit of } \\
\text { GDP, tons per million roubles of GDP) }\end{array}$ & 0.38 & 0,22 \\
\hline $\begin{array}{l}\text { Catching and neutralization of the substances polluting the } \\
\text { atmosphere departing from stationary sources (\%) }\end{array}$ & 76 & 98 \\
\hline Emissions of CO2 (million tons) & 2201 & 2200 \\
\hline Carbon intensity (thousand tons per million roubles of GDP) & 0.07 & 0,03 \\
\hline $\begin{array}{l}\text { Water intake for the use from natural water sources (one million } \\
\mathrm{m}^{3} \text { ) }\end{array}$ & 77640 & 75000 \\
\hline $\begin{array}{l}\text { Water-retaining capacity (billion cubic meters per billion roubles } \\
\text { of GDP) }\end{array}$ & 0.12 & 0.06 \\
\hline Dumping of the polluted sewage (million $\mathrm{m}^{3}$ ) & 15966 & $8000-9000$ \\
\hline $\begin{array}{l}\text { Quantity of the superficial sources of the centralized drinking } \\
\text { water supply compliant to sanitary and epidemiologic standards } \\
\text { (\%) }\end{array}$ & 64.3 & 99 \\
\hline $\begin{array}{l}\text { Volume of industrial and consumption waste formation (million } \\
\text { tons) }\end{array}$ & 4303 & 2500 \\
\hline $\begin{array}{l}\text { Intensity of industrial and consumption waste formation (tons per } \\
\text { million roubles of GDP) }\end{array}$ & 90 & 33.8 \\
\hline $\begin{array}{l}\text { Volume of the used and neutralized industrial and consumption } \\
\text { waste (million tons) }\end{array}$ & 1990.7 & 2250 \\
\hline $\begin{array}{l}\text { Total amount of extraction and production of energy resources } \\
\text { (million tons of fuel equivalent) }\end{array}$ & 1694.0 & $1750-2150$ \\
\hline $\begin{array}{l}\text { Total amount of consumption of energy resources (million tons of } \\
\text { fuel equivalent) }\end{array}$ & 1043.1 & $1200-1300$ \\
\hline $\begin{array}{l}\text { Power consumption (the relation of consumption of energy to } \\
\text { GDP) (\%) }\end{array}$ & 100 & 61 \\
\hline $\begin{array}{l}\text { Renewable power sources (general energy production) (billion } \\
\text { kilowatt -hour) }\end{array}$ & 0.5 & $35-61$ \\
\hline Area of the territory with the forest cover (million hectares) га) & 771 & 790 \\
\hline Share of the territory with the forest cover (in \%) & 47 & 48 \\
\hline $\begin{array}{l}\text { Area of all the especially protected natural territories (million } \\
\text { hectares) }\end{array}$ & 211 & 270 \\
\hline Share of especially protected natural territories in the total area (\%) & 11.7 & 15 \\
\hline $\begin{array}{l}\text { Total amount of the expenses directed to environmental protection } \\
\text { (billion roubles) }\end{array}$ & 91 & 1100 \\
\hline $\begin{array}{l}\text { Investments into fixed capital directed to environmental protection } \\
\text { and rational use of natural resources, } \% \text { to the level of } 2007 \text {. }\end{array}$ & 108 & 203 \\
\hline $\begin{array}{l}\text { Share of the expenses directed to environmental protection in GDP } \\
(\%)\end{array}$ & 0.2 & 1.5 \\
\hline Population, living in especially polluted cities (million people) & 55.1 & $10-12$ \\
\hline
\end{tabular}




\begin{tabular}{|l|c|c|}
\hline $\begin{array}{l}\text { Quantity of the cities with the high and very high level of pollution } \\
\text { of atmospheric air }\end{array}$ & 126 & 34 \\
\hline $\begin{array}{l}\text { Share of the housing stock, equipped with the water supply } \\
\text { systems (\%) }\end{array}$ & 78 & 99 \\
\hline $\begin{array}{l}\text { Share of the city and rural housing stock, equipped with the } \\
\text { sewerage (\%) }\end{array}$ & 74 & 98 \\
\hline Emissions of the firm weighed particles (thousand tons) & 2.3 & $1.5-1.7$ \\
\hline
\end{tabular}

* - Source: report by Productive Force Research Council [8, 9].

Information-and-analytical material with some recommendations of the international conferences and summits on environmental protection and sustainable development, on the measures of the international regulation of anthropogenic influence and stimulation of "green" economy and environmentally friendly sustainable development, on methodological approaches of the international organizations for the reflection of indicators of "green" growth and "green" economy in documents of strategic and predictive character was received, the best foreign practices of the reflection of indicators of "green" growth and the development of "green" economy in documents of predictive character were revealed.

\section{Discussion}

Materials of the research can be used by the experts, who are engaged in studying "green" economy, "green" growth, "green" technologies, sustainable development, greening of the economy, and by the heads, who are responsible for the development of the economy.

Fundamental provisions of the research were included into the books: "Green" economy - a new paradigm of the development of the country" (2015) and "Green" economy: reset" (2017). The latest book was republished in 2018 by LAMBERT Academic Publishing house and Zimorodok publishing house. At the meeting of the State Council "On the Ecological Development of the Russian Federation for the Benefit of Future Generations", which took place on December 27, 2016 the President V.V. Putin noted, that we have on the agenda the phased transition of Russia to model of ecologically sustainable development which includes the increase in the efficiency of all the national economy due to its greening and the improvement of quality of the inhabitants life [10].

The report for the meeting of the State Council, which is in many respects based on the research, completed by authors of the monograph together with the leading ecologists of our country, includes the analysis of the environmental problems, and proves the need of transition to "green", ecologically sustainable development as national strategic priorities. The matters of ecologically sustainable development of Russia, global environmental problems, qualities of the environment in the circumstances of the current load of it, threats of environmental safety of the Russian Federation until 2050 were also considered. Within the preparation of the materials for the State Report the block of decisions on the ecological development in the middle and long term was offered, including:

- changes and additions in the current legislation in the sphere of environmental management and environmental protection;

- multilevel system of motivation;

- creation of pure productions, including through introduction of special market tools;

- complex of actions for the development of renewables.

\section{Conclusions}

According to the results of the research it is possible to draw the following conclusions: 
- considerable analytical material on activity of the international organizations and financial structures in the field of development of "green" economy is accumulated;

- offers on expected indicators and indicators of "green" growth and "green" economy as a part of the forecast of long-term social-and-economic development of the Russian Federation until 2030 are presented;

- the implementation of the principles of "green" economy in activity of specific industries takes place including "green technologies", "green power", "green transport", "green construction", ecosystem services.

Materials of the research can be used by the experts, who are engaged in studying "green economy", "green growth", "green technologies", "sustainable development", "greening of economy" as well as by the heads, who are responsible for the economy development.

Materials of this research were used during the preparation of the meeting of the State Council, which took place on December, 27, 2016, and can be the basis for development of the scientifically proved Concept of transition of the Russian Federation to "green" economy and for the preparation of "Methodological recommendations on the inclusion of an ecological component in investment projects of regions in Russia".

\section{References}

1. G. Dyakova, S. Izmaylova, A. Mottaeva, E. Karanina, IOP Conf. Series: Earth and Environmental Science 90, 012218 (2017) doi :10.1088/1755-1315/90/1/012218

2. S. Rinaldi, M. Pasetti, P. Ferrari, G. Massa, D. Della Giustina, IEEE International Workshop on Applied Measurements for Power Systems (AMPS), 28-30 September 2016, Aachen, Germany (2016). DOI: 10.1109/AMPS.2016.7602860

3. K. Kunanbayeva, A.Gorovoy, A. Butyrin, MATEC Web of Conferences 193, 05048 (2018)

4. M. Alexander, Management Planning for Nature Conservation, Theoretical Basis\&Practical Guide (Springer Books, 2013)

5. I. Markina, A. Sharkova, Journal of Applied Economic Sciences 9(4), 687-693 (2014)

6. M. Pasetti, S. Rinaldi, D. Manerba, Appl Sci-Basel, 8, 3 (2018), 432. DOI: 10.3390/app8030432

7. D.Radushinsky, A. Mottaeva, L. Andreeva, G. Dyakova, IOP Conf. Series: Earth and Environmental Science 90, 012137 (2017) doi :10.1088/1755-1315/90/1/012218

8. I. Markina, A. Sharkova, M. Barna, International Journal of Entrepreneurship 22(3) (2018)

9. I. Markina, A. Sharkova, Journal of Applied Economic Sciences 9(4), 687-693 (2014)

10. A. Shevchuk, I. Komarova, National Security \& Innovation Activities: Methodology, Policy and Practice Monograph (Poland, Bielsko-Biala, 2018) 